\title{
Epidemiologic features and Management of Hypertension in Tunisia, the results from the NAtional TUnisian REgistry of HyperTensioN (NaTuRe HTN) about 25890 patients
}

\section{Leila Abid ( $\nabla$ leilaabidt@yahoo.fr)}

Tunisian Society of Cardiology and Cardiovascular Surgery, Tunis

\section{Rania Hammami}

Cardiology department, Hedi Chaker-Sfax University Hospital, Sfax

Ikram Chatmouri

Cardiology department B, Fattouma Bourguiba University Hospital, Monastir

\section{Meriam Drissa}

Cardiology department, La Rabta 2 (Pr Drissa) University Hospital, Tunis

\section{Selim Boudiche}

Cardiology department, La Rabta 1 (Pr Mourali) University Hospital, Tunis

\section{MohamedAmine Bahloul}

Cardiology department, Hedi Chaker-Sfax University Hospital, Sfax

\section{Hedi BenSlima}

Cardiology department, Hospital of Menzel Bourguiba, Bizerte

\section{Khaled Sayahi}

Cardiology department, ElKef Hospital, Elkef

\section{Selma Charfeddine}

Cardiology department, Hedi Chaker-Sfax University Hospital, Sfax

\section{Emna Allouche}

Cardiology department, Charles Nicole University Hospital, Tunis

\section{Lamia Rais}

Nephrology department, La Rabta University hospital, Tunis

\section{Badr Kaab}

Nephrology department, La Rabta University hospital, Tunis

\section{Hassen IbnHadjamor}

Cardiology department, Tahar Sfar Hospital, Mahdia

\section{Lilia BenFatma}

Nephrology department, La Rabta University hospital, Tunis

\section{Riadh Garbaa}

Cardiologist, Private sector, Medenine

\section{Sabrine Boukhris}

Cardiology department, La Rabta 2 (Pr Drissa) University Hospital, Tunis

\section{Manel Ben Halima}

Cardiology department, La Rabta 1 (Pr Mourali) University Hospital, Tunis

\section{Nesrine Amdouni}

Cardiology department B, Fattouma Bourguiba University Hospital, Monastir Chaima Ghorbel 
Cardiology department, Habib Bourguiba Hospital, Medenine

\section{Sabrine Soudani}

Cardiology department, La Rabta 2 (Pr Drissa) University Hospital, Tunis

\section{Imen Khaled}

General practitioner, CSB, Medenine

\section{Syrine Triki}

Cardiology department, Hedi Chaker-Sfax University Hospital, Sfax

\section{Feten Bouazizi}

General practitioner, CSB, Medenine

Imen Jemai

General practitioner, Habib Bourguiba Hospital, Medenine

\section{Ouday Abdeljalil}

Cardiology department B, Fattouma Bourguiba University Hospital, Monastir

\section{Yemna Ammar}

General practitioner, CSB, Medenine

\section{Amani Farah}

Cardiology department B, Fattouma Bourguiba University Hospital, Monastir

\section{Adnen Neji}

General practitioner, Hospital of Tozeur, Tozeur

\section{Zeineb Oumayma}

Cardiology department, Charles Nicole University Hospital, Tunis

\section{Sana Seghaier}

General practitioner, Private sector, Tunis

\section{Samir Mokrani}

General practitioner, Hospital of Mateur, Bizerte

\section{Hamza Thawaba}

Cardiologist, Private sector, Mahdia

\section{Hela Sarray}

Cardiology department, Hedi Chaker-Sfax University Hospital, Sfax

\section{Khalil Ouaghlani}

Cardiology department, Charles Nicole University Hospital, Tunis

\section{Houssem Thabet}

Cardiology department, Farhat Hached Hospital, Sousse

\section{Zeineb Mnif}

Cardiologist, NSSF, Sfax

\section{Fatma Boujelban}

Cardiologist, Private sector, Sfax

\section{Mohamed Sghaier}

Cardiologist, Private sector, Ben Arous

\section{Roueida Khalifa}

Cardiology department B, Fattouma Bourguiba University Hospital, Monastir

\section{Sami Fourati}

Cardiologist, Private sector, Sfax

\section{Yasmin Kammoun}

Cardiology department, Hedi Chaker-Sfax University Hospital, Sfax

\section{Syrine Abid}


Cardiologist, Private sector, Tunis

\section{Chihab Hamza}

Cardiologist, Private sector, Tunis

\section{Syrine Ben Jeddou}

Cardiology department, La Rabta 2 (Pr Drissa) University Hospital, Tunis

\section{Lassaad Sabbah}

General practitioner, Private sector, Sfax

\section{Rim Lakhdhar}

Cardiologist, Private sector, Ariana

\section{Najla Dammak}

Nephrology department, Hedi Chaker-Sfax University Hospital, Sfax

\section{Tarek Sellami}

Cardiologist, Private sector, Kebeli

\section{Basma Herbegue}

Cardiologist, Private sector, Ariana

\section{Alia Koubaa}

General Practitioner, CSB, Ben Arous

\section{Faten Triki}

Cardiology department, Hedi Chaker-Sfax University Hospital, Sfax

Tarek Ellouz

Cardiology department, Hedi Chaker-Sfax University Hospital, Sfax

\section{Aicha Hmoudi}

General Practitioner, CSB, Tataouine

\section{Ikhlas BenAmeur}

Cardiologist, Private sector, Sfax

\section{MohamedMongi Boukhchina}

General practitioner, Private sector, Gabes

\section{Neila Abid}

General practitioner, Private sector, Sfax

\section{Wejdene Wachtati}

Cardiology department, Charles Nicole University Hospital, Tunis

\section{Nizar Nasrallah}

General practitioner, Private sector, Ariana

\section{Yousra Houidi}

General Practitioner, CSB, Tunis

\section{Fathia Meghaieth}

Cardiology department, La Rabta 1 (Pr Mourali) University Hospital, Tunis

\section{Elhem Ghodhbane}

General Practitioner, CSB, Tataouine

\section{Mounira Chayeb}

General Practitioner, CSB, Tunis

\section{Sarra Chenik}

Cardiology department, The Main Military Instruction Hospital of Tunis, Tunis

\section{Samira Kaabachi}

General practitioner, La Rabta 2 (Pr Drissa) University Hospital, Tunis

\section{Nizar Saadaoui}


Cardiologist, Private sector, Sfax

Ines BenAmeur

Cardiologist, Private sector, Sfax

Moufida Affes

General practitioner, Private sector, Sfax

Sana Ouali

Cardiology department, La Rabta 1 (Pr Mourali) University Hospital, Tunis

Mouna Chaker

Cardiology department, Hedi Chaker-Sfax University Hospital, Sfax

Hela Naanaa

Cardiologist, Private sector, Nabeul

Meriem Dghim

Cardiology department, The Main Military Instruction Hospital of Tunis, Tunis

Mourad Jarrar

Cardiologist, Private sector, Sousse

Jihene Mnif

Cardiologist, Private sector, Sfax

Ahmed Turki

Cardiology department, Hedi Chaker-Sfax University Hospital, Sfax

Ihsen Zairi

Cardiology department, Habib Thameur Hospital, Tunis

Jamel Langar

Cardiologist, Private sector, Nabeul

\section{Safa Dardouri}

Cardiology department, Farhat Hached Hospital, Sousse

Imen Hchaichi

General Practitioner , CSB, Gabes

\section{Rafik Chettaoui}

Cardiologist, Private sector, Ariana

Wajih Essmat

Cardiologist, Private sector, Gafsa

\section{Amel Chakroun}

General practitioner, Hospital of Habib Bougatfa, Bizerte

Khadija Mzoughi

Cardiology department, Habib Thameur Hospital, Tunis

Rachid Mechmeche

Cardiologist, Private sector, Tunis

Afef BenHalima

Cardiology department, Abderrahmen Mami-Ariana Hospital, Ariana

Sahar BenKhala

Cardiology department, Mahres Hospital, Sfax

Slim Chtourou

Cardiologist, Private sector, Sfax

\section{Abdelkader Maalej}

Cardiologist, Private sector, Sfax

Mohsen Ayari 
General practitioner, Private sector, Nabeul

\section{Moufid Hadrich}

Cardiologist, Private sector, Ariana

\section{Rami Tlili}

Cardiology department, Mongi Slim Hospital, Tunis

\section{Fares Azaiez}

Cardiology department, Mongi Slim Hospital, Tunis

Imen Bouhlel

Cardiology department, Farhat Hached Hospital, Sousse

\section{Samira Sahnoun}

General practitioner, Private sector, Sfax

\section{Habib Jerbi}

General practitioner, Private sector, Sousse

\section{Imtinene BenMrad}

Cardiology department, Habib Thameur Hospital, Tunis

\section{Leila Riahi}

Cardiology department, The Main Military Instruction Hospital of Tunis, Tunis

\section{Mohamed Sahnoun}

Cardiologist, Private sector, Sfax

\section{Abdelhamid BenJemaa}

Cardiology department, Hedi Chaker-Sfax University Hospital, Sfax

Amel BenSalem

Cardiology department, Charles Nicole University Hospital, Tunis

\section{Bassem Rekik}

Cardiology department, Charles Nicole University Hospital, Tunis

\section{Maroua BenDoudou}

Cardiology department, Habib Thameur Hospital, Tunis

\section{Rachid Boujneh}

Cardiologist, Private sector, Tunis

\section{Anissa Joulak}

Cardiologist, Private sector, Tunis

\section{Yosra Mejdoub}

Community Medicine department, Hedi Chaker-Sfax University Hospital, Sfax

Imen gtif

Laboratory of Screening Cellular and Molecular Process, Centre of Biotechnology of Sfax, Sfax

\section{Gouider Jribi}

Cardiology department, Farhat Hached Hospital, Sousse

\section{Elyes Naffeti}

Cardiology department, University hospital Sahloul, Sousse

\section{Habib Gamra}

Cardiology department A, Fatouma Bourguiba Hospital, Monastir

\section{Soraya BenYousef}

Cardiology department, Internal Security Forces Hospital, Tunis

Wissem Sdiri

Cardiology department, Bougatfa Hospital, Bizerte

\section{Najeh BenHalima}


Cardiology department, Ibn El Jazzar Hospital, Kairouan

Youssef BenAmeur

Cardiology department, Mongi Slim Hospital, Tunis

Salem Kachboura

Cardiology department, Abderrahmen Mami-Ariana Hospital, Ariana

Sondes Kraiem

Cardiology department, Habib Thameur Hospital, Tunis

Wafa Fehri

Cardiology department, The Main Military Instruction Hospital of Tunis, Tunis

Leila Bazdeh

Cardiology department, Charles Nicole University Hospital, Tunis

\section{MohamedSami Mourali}

Cardiology department, La Rabta 1 (Pr Mourali) University Hospital, Tunis

\section{Sami Milouchi}

Cardiology department, Habib Bourguiba Hospital, Medenine

\section{Habiba Drissa}

Cardiology department, La Rabta 2 (Pr Drissa) University Hospital, Tunis

Faouzi Maatouk

Cardiology department B, Fattouma Bourguiba University Hospital, Monastir

\section{Lilia Zakhama}

Cardiology department, Internal Security Forces Hospital, Tunis

\section{Faouzi Addad}

Cardiology department, Abderrahmen Mami-Ariana Hospital, Ariana

\section{Samir Kammoun}

Cardiology department, Hedi Chaker-Sfax University Hospital, Sfax

\section{Salem Abdesselem}

Cardiologist, Private sector, Tunis

\section{Research Article}

Keywords: Hypertension, Blood pressure control, Epidemiology, Predictors, Registry

Posted Date: September 16th, 2021

DOI: https://doi.org/10.21203/rs.3.rs-832483/v1

License: @ (i) This work is licensed under a Creative Commons Attribution 4.0 International License. Read Full License 


\section{Abstract}

\section{Background}

Hypertension is the leading cause of morbi-moratlity in low, middle as well as high incomes countries. Tunisia is a developing country with a high cardiovascular profile and the prevalence of hypertension has widely increased during the last decades. Thus, we conducted this national survey on hypertension to analyze the profile of the Tunisian hypertensive patient and to assess the level of blood pressure control.

\section{Methods}

Nature HTN is an observational multicentric survey, including hypertensive individuals and consulting their doctors during the period of the study. The primary endpoint of our study was uncontrolled hypertension defined by a systolic blood pressure $\geq 140 \mathrm{mmHg}$ and/or diastolic blood pressure $\geq 90 \mathrm{mmHg}$. Our objective is to assess the predictors of uncontrolled hypertension in our population.

\section{Results}

Three hundred twenty one investigators from all the Tunisian governorates participated in the study. We enrolled 25890 patients with a female predominance (Sex ratio 1.21) and an average age $64.4 \pm 12.2$ year-old. Most of individuals were treated in the public sector (74\%), $39.4 \%$ of patients were diabetic, $25.8 \%$ were obese, $44.6 \%$ were overweight and $14 \%$ were smokers. Hypertension was controlled in $51.7 \%$ of cases if we consider $140 / 90$ as BP target and only in $18.6 \%$ if we consider $130 / 80$ as a target. The independents predictors of uncontrolled blood pressure were male sex $(0 \mathrm{R}=1.09,95 \% \mathrm{Cl}$ [1.02-1.16]), age > 65 year-old (OR=1.07, 95\% Cl[1.01-1.13], diabetes (OR=1.18, 95\% Cl [1.11-1.25], Smoking (OR=1.15, 95\% $\mathrm{Cl}$ [1.05-1.25]), Obesity (OR=1.14, 95\% Cl[1.07-1.21]), management in public sector $(\mathrm{OR}=1.25,95 \% \mathrm{Cl}$ [1.16-1.34]) and Heart rate $>80 \mathrm{bpm}(\mathrm{OR}=1.59,95 \% \mathrm{Cl}[1.48-1.71])$. Contrarily, high educational level $(\mathrm{OR}=0.9,95 \% \mathrm{Cl}$ [0.84-0.97], absence of history of coronary disease $(\mathrm{OR}=0.86,95 \% \mathrm{Cl}[0.8-0.93])$, salt restriction $(\mathrm{OR}=0.48,95 \% \mathrm{Cl}[0.45-0.51])$, drug compliance $(\mathrm{OR}=0.57$, $95 \% \mathrm{CI}[0.52-0.61])$ and regular physical activity $(\mathrm{OR}=0.77,95 \% \mathrm{CI}[0.71-0.84])$ are strong predictors of blood pressure control.

\section{Conclusion}

Nature HTN showed a remarkable improvement of blood pressure control amongst Tunisian people. The control remains low in patients with high cardiovascular profile and those treated in the public sector. A national health program based on therapeutic education, regular control and continuous giving much support to the public institutions is needed to decrease the hypertension burden affection rate in our population.

\section{Background}

Hypertension is the most common chronic disease in the world with a prevalence ranging between 30 and $50 \%$, and it is considered to be the leading cause of morbi-mortality in adults especially in low and middle incomed countries [1-5]. The prevalence is higher in the elderly and exceeds $60 \%$ in people aged $>60$ years [3]. Given the widespread of sedentary lifestyles and obesity, the prevalence of hypertension worldwide will continue to rise. It is estimated that the number of hypertensive people will increase by $15-20 \%$ by 2025 , reaching close to 1.5 billion [2]. Several recent epidemiological studies demonstrated that high blood pressure is under diagnosed in the 5 continents of the world and despite the development of the therapeutic arsenal, the control of hypertension does not seem to improve in most countries [4, 6-10]. In Tunisia, a middle income developing country, the latest epidemiological data related to hypertension dates back to 2012 , from the national survey "TAHINA Study"[11]. The lifestyle of Tunisian people has widely changed in last years with an increase of sedentarity, overweight and obesity, diabetes and dyslipidemia... Tunisia is considered as a high cardiovascular risk country [12] and the world health organization as well as other international organizations estimate that the Tunisian 
epidemiologic situation will worsen in next years [13]. The main reason why we envisioned the need for a national multicentric survey to analyze the epidemiologic profile of hypertension in Tunisia and to assess the level of blood pressure control as well as the predictor of uncontrolled hypertension.

\section{Patients And Methods}

Nature HTN registry is an observational multi-centric national study, conducted in all the governorates of Tunisia, in both public and private health sectors. Patients were included between 15 April 2019 and 15 May 2019 (Ramadan in between). Different investigators ensured the enrollment and the clinical examination: Cardiologists, General doctors as well others specialists as Nephrologists, Endocrinologists and Internists. We included all patients with known or new diagnosed hypertension, who consulted their doctors during the enrollment period.

\section{Inclusion Criteria}

We included during the office visits, patients with a history of or newly diagnosed elevated blood pressure and older than 18 year-old, after signing a consent form.

Except when hypertension is severe (e.g. grade 3 and especially in high-risk patients), the diagnosis of new hypertension was confirmed according to the ESC/ESH guidelines as either Out-of-office Blood Pressure (BP) measurement above the recommended thresholds or repeated office BP measurements on more than one visit above $140 \mathrm{mmHg}$ for the systolic pressure and /or 90 mmHgfor the diastolic pressure [14].

\section{Exclusion Criteria}

We excluded from the study, patients undergoing hemodialysis, pregnant women, those classified as white coat hypertension patients and those who refused to sign the consent form.

\section{Clinical evaluation and data collection}

During the office visit, the physician had to complete the case report form of the registry after patient's interrogation and examination.

Information's on socio-demographic characteristics including age, gender, education level, health insurance, smoking, diabetes, pulmonary diseases, hypothyroidism, moderate renal failure history (defined by an MDRD creatinine clearance < $60 \mathrm{ml} / \mathrm{min}$ [15]), coronary disease as well as history of stroke were collected.

The interview-included questions related to drug compliance and salt intake as well as sport practice. The physical activity was considered as regular when it was performed at least 30 minutes three times a week [14].

On physical exam, we measured weight and height to assess body mass index (BMI = weight/height ${ }^{2}$. Obesity is operationally defined as a BMI exceeding $30 \mathrm{~kg} / \mathrm{m}^{2}$ and is subclassified into moderate (BMl:30-34.9), morbid (BMI:3539.9) and severe $(\mathrm{BMI} \geq 40)[16]$. Blood pressure measurements were conducted using a standardized auscultatory or oscillometric sphygmomanometer after at least $15 \mathrm{~min}$ of rest. Two separate readings were taken at least three minutes apart and we considered the average of the two measurements. In patients with asymmetric blood pressure between the two arms, we considered the higher pressure.

We checked on electrocardiogram whether the patient had a sinus rhythm or atrial fibrillation and we searched for left ventricle hypertrophy (LVH) based on the definition recommended by the ESC/ESH guidelines (Sokolow-Lyon index > 35 $\mathrm{mm}$, or $\mathrm{R}$ in aVL >_11 mm) [14]. We searched for LVH also on echocardiographic findings (if the patient underwent echocardiography during the last year). 
We noted also the last biology tests, performed during the last six months before the office visit, especially creatinine, glycaemia, cholesterol and kaliemia as well as microalbuminuria (if performed during the last year).

To assess control blood pressure, we evaluated only patients with diagnosed hypertension for more than 6 months. The primary endpoint in our study was the rate of hypertension control.

Uncontrolled hypertension was defined according to the ESC/ESH guidelines as an average systolic blood pressure(SBP) above $140 \mathrm{mmHg}$ and/or an average diastolic blood pressure (DBP) above $90 \mathrm{mmHg}$ [14].

A validation of the study protocol and the consent form by a national ethic committee was also obtained.

The data collected, were managed by the Clinical Suite platform (Dacima Software), which complies with international standards including US Food and Drug Administration 21 Code of Federal Regulations Part 11, US Health Insurance Portability and Accountability Act, International Conference on Harmonisation, and Medical Dictionary for Regulatory Activities. The Clinical Suite platform allowed us to track the data entered and to check for inconsistencies and missing data. A steering committee was set up to monitor patient inclusions, verify data sources, perform the audit trail, and prepare the statistical analysis plan for the study.

We confirm that all methods were carried out in accordance with relevant guidelines and regulations. All experimental protocols were approved by the ethic committee of the Hospital of the Internal Security Forces. An informed written consent was obtained from all subjects. In case of illiterate participants informed consent was obtained from legal guardians.

\section{Statistical analysis}

All statistical analyses were achieved using the SPSS 23.0 (SPSS, Chicago, IL, USA) statistical package. Continuous variables were presented as means value \pm standard deviation in case of Gaussian distribution and as medians as well as extremes values in case of non-Gaussian distribution.

Among patients with old hypertension more than 6 months, we distinguished two groups according to the hypertension control (controlled group versus uncontrolled group). The comparison between the two groups was achieved by Student's ttest and Chi2 test for continuous variables and categorical variables, respectively. Univariate logistic regression analyses were used to determine crude odds ratio with the $95 \%$ approximate confidence intervals as estimators of the non-control of hypertension for various characteristics of the study population. To assess the predictors of hypertension non control, we performed a multivariate logistic regression model. The significance threshold was set at $p<0.05$.

\section{Results}

The Nature HTN registry concerned 25890 hypertensive patients, enrolled by 321 investigators from all the Tunisian governorates. The case report form was completed by Cardiologists in $71 \%$ of patients, general practitioner in $25 \%$ and others specialists in $4 \%$. The patients were managed in public as well as private sector but the majority of patients were followed in public centers (78\%). The hypertension was newly diagnosed in 2286 patients (8.8\%) and in the medical history/record of more than six months in 23601 persons.

The majority of patient $(16565,64 \%)$ were included during Ramadan, especially for private sector.

The epidemiologic and clinic characteristics of the overall population are summarized in Table 1. 
Table 1

Epidemiologic and clinic chracteristics of the population according to the sex and the management sector

\begin{tabular}{|c|c|c|c|c|c|c|c|}
\hline & $\begin{array}{l}\text { All } \\
\text { population }\end{array}$ & Female & Male & $\begin{array}{l}\text { p } \\
\text { (male } \\
\text { vs } \\
\text { female) }\end{array}$ & Public & Private & $\begin{array}{l}\text { P } \\
\text { (public } \\
\text { vs } \\
\text { private) }\end{array}$ \\
\hline $\mathrm{N}$ & 25890 & 14166 & 11700 & & 20192 & 5698 & \\
\hline \multirow{3}{*}{$\begin{array}{l}\text { Age (years) } \\
\text { Median (min-max) } \\
\text { Mean } \pm \text { SD }\end{array}$} & \multirow{2}{*}{$\begin{array}{l}64.00(18- \\
118)\end{array}$} & $64(18-118)$ & 64(18-108) & \multirow[t]{3}{*}{$0.059 *$} & \multirow{3}{*}{$\begin{array}{l}64(18-118) \\
64.46 \pm 12.2\end{array}$} & 65(18- & \multirow[t]{3}{*}{0.4} \\
\hline & & \multirow[t]{2}{*}{$64.5 \pm 12.2$} & \multirow{2}{*}{$64.2 \pm 12.2$} & & & & \\
\hline & $64.4 \pm 12.2$ & & & & & $\begin{array}{l}64.19 \pm \\
12.1\end{array}$ & \\
\hline Age > 65 yo (\%) & $12662(49.3)$ & 6982(49.7) & $5673(48.8)$ & 0.1 & $9860(49.1)$ & $\begin{array}{l}2802 \\
(50.1)\end{array}$ & 0.4 \\
\hline $\begin{array}{l}\text { Ramadan } \\
\text { Inclusion (\%) }\end{array}$ & $16565(64)$ & $9155(64.6)$ & 7403(63.3) & 0.02 & $\begin{array}{l}13173 \\
(35.2)\end{array}$ & $3392(59.5)$ & $<10^{-3}$ \\
\hline Education level & $5527(21.3)$ & $4261(30.1)$ & 1262(10.8) & $<10^{-3}$ & 4527(22.4) & $1000(17.6)$ & \multirow[t]{6}{*}{$<10^{-3}$} \\
\hline Illiterate (\%) & $5475(21.1)$ & $3124(22.1)$ & 2346(20.1) & & 4384(21.7) & 1091(19.1) & \\
\hline Primary school (\%) & 4493(17.4) & 1880(13.3) & 2612(22.3) & & 3139(15.5) & 1354(23.8) & \\
\hline $\begin{array}{l}\text { Secondary school } \\
(\%)\end{array}$ & 2428(9.4) & $825(5.8)$ & 1600(13.7) & & 1439(7.1) & $989(17.4)$ & \\
\hline $\begin{array}{l}\text { University school } \\
(\%)\end{array}$ & 7967(30.8) & $4076(28.8)$ & $3880(33.2)$ & & 6703(33.2) & $1264(22.2)$ & \\
\hline Unprecised (\%) & & & & & & & \\
\hline \multirow{3}{*}{$\begin{array}{l}\text { Health insurance } \\
\text { coverage } \\
\text { Private insurance } \\
(\%)\end{array}$} & $762(2.9)$ & $399(2.8)$ & $363(3.1)$ & $<10^{-3}$ & $434(2.1)$ & $328(5.8)$ & \multirow[t]{7}{*}{$<10^{-3}$} \\
\hline & 18453(71.3) & $9806(69.2)$ & 8632(73.8) & & $14165(70.2)$ & $4285(75.2)$ & \\
\hline & $5052(19.5)$ & $3114(22)$ & 1936(16.5) & & 4724(23.4) & $328(5.8)$ & \\
\hline \multirow{2}{*}{$\begin{array}{l}\text { National insurance } \\
(\%)\end{array}$} & $790(3.1)$ & $408(2.9)$ & 382(3.3) & & $520(2.6)$ & $270(4.7)$ & \\
\hline & 833(3.2) & $439(3.1)$ & $387(3.3)$ & & $346(1.7)$ & 487(8.5) & \\
\hline $\begin{array}{l}\text { None insurance } \\
(\%)\end{array}$ & & & & & & & \\
\hline \multicolumn{2}{|l|}{ Unprecised (\%) } & & & & & & \\
\hline Smoking (\%) & $3630(14)$ & $391(2.8)$ & $3236(27.7)$ & $<10^{-3}$ & $3021(15)$ & $609(10.7)$ & $<10^{-3}$ \\
\hline Diabetes (\%) & $\begin{array}{l}10204 \\
(39.4)\end{array}$ & $5621(39.7)$ & 4583(39.2) & 0.4 & $8185(40.5)$ & $\begin{array}{l}2029 \\
(35,6)\end{array}$ & $<10^{-3}$ \\
\hline Obesity (\%) & 6979 (25.8) & 4927 (34.7) & 2065 (17.6) & $<10^{-3}$ & 5207 ( 25.9) & $\begin{array}{l}2590 \\
(46.3)\end{array}$ & $<10^{-3}$ \\
\hline
\end{tabular}

*mann-whitney nonparametric test

ABPM: Ambulatory blood pressure monitoring, ACE: Antagonist of conversion enzyme, ARB: Angiotensin Receptor Blockers, BMI: Body mass Index, CCB: Calcium Channels Blockers, COPD: Chronic obstructive pulmonary disease, DBP: Diastolic Blood Pressure, EKG: electrocardiogram, HTN: hypertension, LVH: Left Ventricle Hypertrophy, SD: Standard Deviation, SBP: systolic Blood Pressure, SMBP: Self measured Blood Pressure, TTE: Transthoracic echocardiography, yo: year-old 


\begin{tabular}{|c|c|c|c|c|c|c|c|}
\hline & $\begin{array}{l}\text { All } \\
\text { population }\end{array}$ & Female & Male & $\begin{array}{l}p \\
\text { (male } \\
\text { vs } \\
\text { female) }\end{array}$ & Public & Private & $\begin{array}{l}\text { p } \\
\text { (public } \\
\text { vs } \\
\text { private) }\end{array}$ \\
\hline \multirow{4}{*}{$\begin{array}{l}\text { Corpulence } \\
\text { overweight (\%) } \\
\text { moderate obesity } \\
(\%) \\
\text { morbid obesity (\%) } \\
\text { severe obesity (\%) }\end{array}$} & $11539(44.6)$ & $5984(42.2)$ & $5546(47.4)$ & \multirow[t]{4}{*}{$<10-3$} & $9454(46.8)$ & 2085(36.6) & \multirow[t]{4}{*}{$<10^{-3}$} \\
\hline & $5182(20)$ & $3509(24.8)$ & 1671(14.3) & & $3946(19.5)$ & 1236(21.7) & \\
\hline & $461(1.8)$ & $375(2.6)$ & $85(0.7)$ & & $302(1.5)$ & $959(2.8)$ & \\
\hline & $1354(5.2)$ & $1043(7.4)$ & $310(2.6)$ & & $959(4.7)$ & $395(6.9)$ & \\
\hline \multirow{2}{*}{$\begin{array}{l}\mathrm{BMI}\left(\mathrm{Kg} / \mathrm{cm}^{2}\right) \\
\text { Median ( min- } \\
\text { max) } \\
\text { Mean } \pm \mathrm{SD}\end{array}$} & $\begin{array}{l}27.5(13.7- \\
72.2)\end{array}$ & $\begin{array}{l}28.3(14- \\
70)\end{array}$ & $27.07 \pm 3.93$ & \multirow[t]{2}{*}{$<10^{-3 \star}$} & $\begin{array}{l}27.3(14- \\
72)\end{array}$ & $\begin{array}{l}29(13.7- \\
66.9)\end{array}$ & \multirow[t]{2}{*}{$<10^{-3 *}$} \\
\hline & $28.1 \pm 4.57$ & $29.01 \pm 4.57$ & & & $27.9 \pm 4.3$ & $\begin{array}{l}29.08 \pm \\
5.13\end{array}$ & \\
\hline $\begin{array}{l}\text { Newly diagnosed } \\
\text { HTN (\%) }\end{array}$ & $1475(5.7)$ & $705(5.1)$ & $770(6.8)$ & $<10^{-3}$ & $953(4.7)$ & $522(9.2)$ & $<10^{-3}$ \\
\hline $\begin{array}{l}\text { Moderate Renal } \\
\text { Failure (\%) }\end{array}$ & $1524(5.9)$ & $672(4.7)$ & $851(7.3)$ & $<10^{-3}$ & $1305(6.5)$ & 219(3.8) & $<10^{-3}$ \\
\hline $\begin{array}{l}\text { Hypothyroidism } \\
\text { (\%) }\end{array}$ & $1384(5.3)$ & 1136(8) & $248(2.1)$ & $<10^{-3}$ & $1034(5.1)$ & $350(6.1)$ & 0.002 \\
\hline Apnea syndrome & $469(1.8)$ & $257(1.8)$ & 211(1.8) & 0.02 & $276(1.4)$ & 193(3.4) & $<10^{-3}$ \\
\hline Confirmed (\%) & $843(3.3)$ & 499(3.5) & $343(2.9)$ & & $505(2.5)$ & $338(5.9)$ & \\
\hline \multicolumn{8}{|l|}{ Suspected (\%) } \\
\hline COPD (\%) & $519(2)$ & 137(1) & $382(3.3)$ & $<10^{-3}$ & $380(1.9)$ & $139(2.4)$ & 0.008 \\
\hline Stroke history (\%) & $1707(6.6)$ & $796(5.6)$ & $910(7.8)$ & $<10^{-3}$ & $1311(6.5)$ & $396(6.9)$ & 0.2 \\
\hline $\begin{array}{l}\text { Coronary disease } \\
(\%)\end{array}$ & 4797(18.5) & 1742(12.3) & $3048(26.1)$ & $<10^{-3}$ & 3941(19.8) & $856(15)$ & $<10^{-3}$ \\
\hline SBP (mmHg) & $\begin{array}{l}135(80- \\
260)\end{array}$ & $\begin{array}{l}135(80- \\
260)\end{array}$ & $\begin{array}{l}140(85- \\
250)\end{array}$ & $<10^{-3 \star}$ & $\begin{array}{l}140(80- \\
260)\end{array}$ & $\begin{array}{l}134.5(80- \\
260)\end{array}$ & $0.1^{*}$ \\
\hline $\begin{array}{l}\text { Median ( min- } \\
\text { max) } \\
\text { Mean } \pm \text { SD }\end{array}$ & $138.8 \pm 19.6$ & $138.5 \pm 19.7$ & $139.2 \pm 19.4$ & & $138.9 \pm 19.7$ & $138.6 \pm 19$ & \\
\hline DBP $(\mathrm{mmHg})$ & $80(40-140)$ & $80(40-140)$ & $80(40-140)$ & \multirow[t]{3}{*}{$0.005^{\star}$} & $80(40-140)$ & \multirow{3}{*}{$\begin{array}{l}80(40- \\
140) \\
79.4 \pm 10.7\end{array}$} & \multirow[t]{3}{*}{$0.6^{\star}$} \\
\hline $\begin{array}{l}\text { Median ( min- } \\
\text { max) }\end{array}$ & $79.03 \pm 11.1$ & $78.8 \pm 10.9$ & $79.3 \pm 11.3$ & & $78.9 \pm 11.2$ & & \\
\hline Mean \pm SD & & & & & & & \\
\hline
\end{tabular}

*mann-whitney nonparametric test

ABPM: Ambulatory blood pressure monitoring, ACE: Antagonist of conversion enzyme, ARB: Angiotensin Receptor Blockers, BMI: Body mass Index, CCB: Calcium Channels Blockers, COPD: Chronic obstructive pulmonary disease, DBP: Diastolic Blood Pressure, EKG: electrocardiogram, HTN: hypertension, LVH: Left Ventricle Hypertrophy, SD: Standard Deviation, SBP: systolic Blood Pressure, SMBP: Self measured Blood Pressure, TTE: Transthoracic echocardiography, yo: year-old 


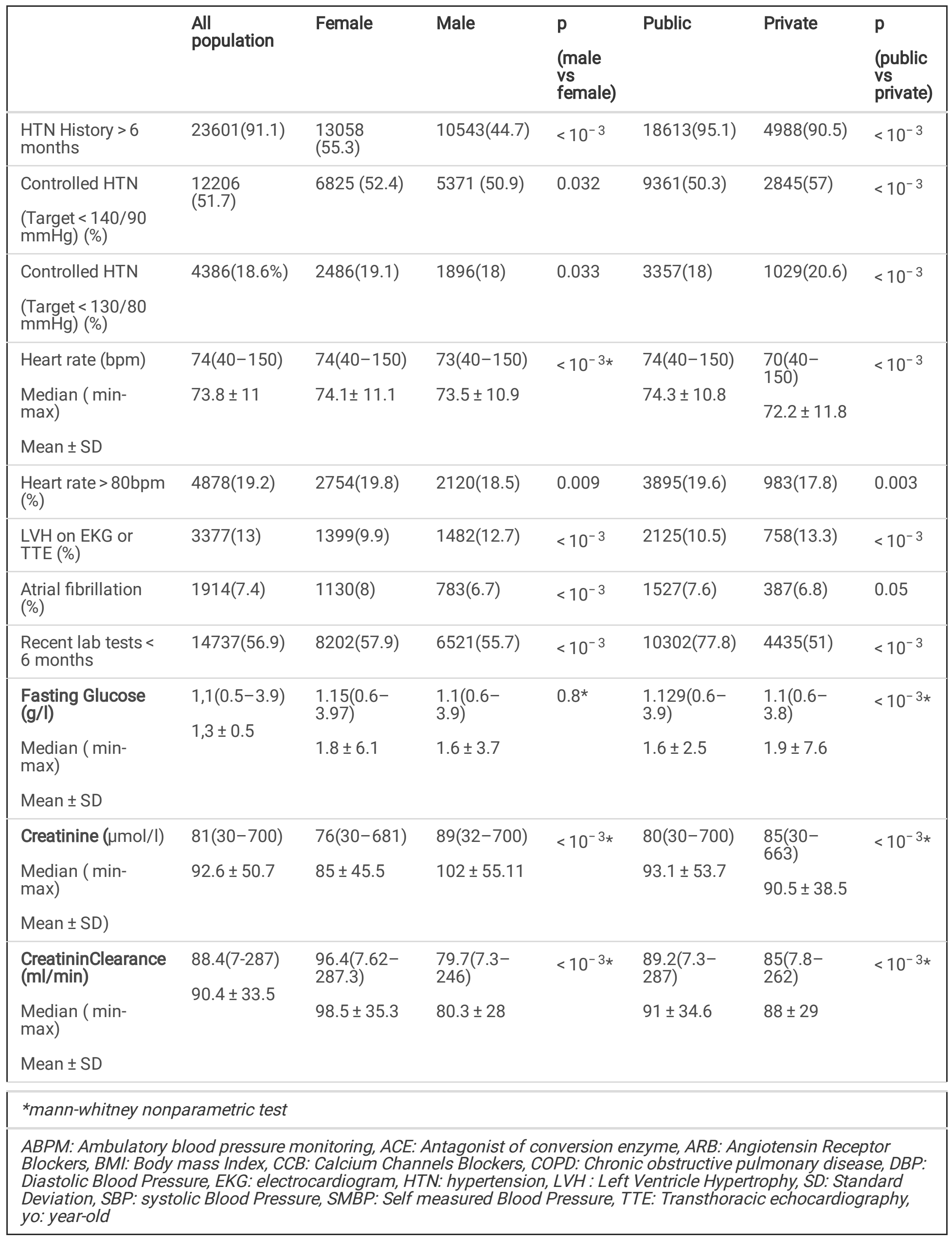




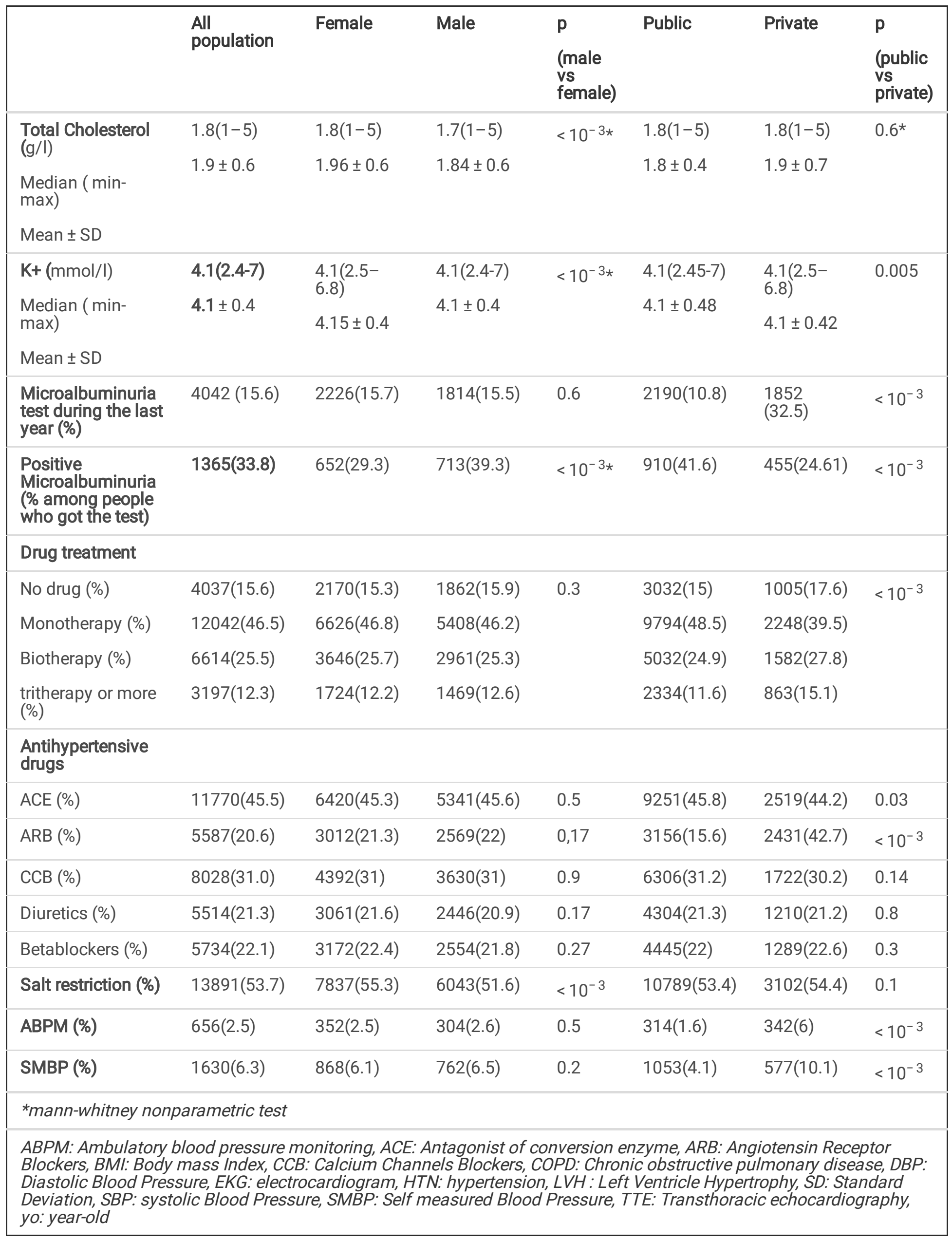




\begin{tabular}{|c|c|c|c|c|c|c|c|}
\hline & $\begin{array}{l}\text { All } \\
\text { population }\end{array}$ & Female & Male & $\begin{array}{l}\text { p } \\
\text { (male } \\
\text { vs } \\
\text { female) }\end{array}$ & Public & Private & $\begin{array}{l}\text { P } \\
\text { (public } \\
\text { vs } \\
\text { private) }\end{array}$ \\
\hline $\begin{array}{l}\text { Drug compliance } \\
\text { (\%) }\end{array}$ & 19539(75.5) & 10874(76.8) & $8651(73.9)$ & $<10^{-3}$ & $15326(75.9)$ & 4213(73.9) & 0.002 \\
\hline $\begin{array}{l}\text { Physical activity } \\
\text { (\%) }\end{array}$ & $3845(14.9)$ & 1598(11.3) & 2243(19.2) & $<10^{-3}$ & 2748(13.6) & 1097(19.3) & $<10^{-3}$ \\
\hline \multicolumn{8}{|c|}{ *mann-whitney nonparametric test } \\
\hline \multicolumn{8}{|c|}{$\begin{array}{l}\text { ABPM: Ambulatory blood pressure monitoring, ACE: Antagonist of conversion enzyme, ARB: Angiotensin Receptor } \\
\text { Blockers, BMl: Body mass Index, CCB: Calcium Channels Blockers, COPD: Chronic obstructive pulmonary disease, DBP: } \\
\text { Diastolic Blood Pressure, EKG: electrocardiogram, HTN: hypertension, LVH: Left Ventricle Hypertrophy, SD: Standard } \\
\text { Deviation, SBP: systolic Blood Pressure, SMBP: Self measured Blood Pressure, TTE: Transthoracic echocardiography, } \\
\text { yo: year-old }\end{array}$} \\
\hline
\end{tabular}

The mean age of our population was $64.0 \pm 12$.3years (extremes: $18-108$ years); the half of our patient (49.3\%) were aged more than 65 year-old. There was a female predominance (sex ratio $=1.22$ ). About $21.3 \%$ of the population was illiterate and only $9.4 \%$ got a university education. The rate of illiteracy was higher in women than in men $(30.1 \%$ in female versus $10.8 \%$ in male). The majority of the model had a national health insurance (71.3\%), a private insurance was more frequently noted in patients treated in private sector (5.8\% versus $2.1 \%$ ). The most associated risk factors were diabetes in $39.4 \%$ and obesity in $25.8 \%$. Overweight or obesity were noted in $70.4 \%$. The mean BMI of the population study was $28.1 \pm 4.57$, it was significantly higher in women than in man $(p<0.001)$, and obesity was more prevalent in female patients than in male (34.8\% versus $17.6 \%$ ). One patient out of four had a history of cardiovascular events (coronary disease or/ and strokes), it means at very high cardiovascular risk.

The mean SBP during the visit office was $138.8 \pm 19.6 \mathrm{mmHg}$ and the mean DBP was $79.03 \pm 11.1 \mathrm{mmHg}$. Using the cutpoint of $140 / 90 \mathrm{mmHg}$ as a BP target, $51.8 \%$ of our patients had a controlled BP, but using the lower cut off recommended by the ACC/AHA of $130 / 80 \mathrm{mmHg}$, only $18.6 \%$ were controlled. Both DBP and SBP were significantly higher in man compared to women, but there were no significant differences between the private and the public sector. Women were also more likely to present atrial fibrillation ( $8 \%$ versus $6.7 \%, p<0.001)$ and hypothyroidism ( $8 \%$ versus $2.1 \%, p<0.001)$. Female patients were significantly more controlled than male (52.3\% versus $50.9 \%, p=0.032)$; Generally the male gender was found as an independent predictor of uncontrolled hypertension. In fact women were significantly more compliant to drug intake $\left(76.6 \%\right.$ versus $\left.73.9 \%, p<10^{-3}\right)$ and to salt restriction $\left(55.3 \%\right.$ versus $\left.51.6 \%, p<10^{-3}\right)$. Contrarily, men performed physical activities more frequently $(p<10-3)$.

The patients who were treated in the public sector were more frequently smokers $\left(15 \%\right.$ versus $\left.10.7 \%, p<10^{-3}\right)$ and diabetics $\left(40.5 \%\right.$ versus $35.6 \%, \mathrm{p}<10^{-3}$ ) compared to those treated in the private sector, but they performed less BP out office measurement. Moreover, they had less frequent physical activities $\left(13.6 \%\right.$ versus $\left.19.3 \%, p<10^{-3}\right)$. Thus, the rate of BP control was better in private sector ( $57 \%$ versus $50.3 \%, p<10^{-3}$ when we consider $140 / 90 \mathrm{mmHg}$ as target).

The mean number of prescribed drug was $1.49 \pm 0.6$, but $46.5 \%$ were on monotherapy and only $37.8 \%$ received two antihypertensive treatments or more. The percentage of multiple drugs ( 2 or more) was higher in the private sector (42.9\% versus 36.5\%). An Antagonist of Conversion Enzyme (ACE) or an Angiotensin Receptor Blockers (ARB) were used in two patients out of three. The ACE class was more frequently prescribed in the public sector whereas the ARB class was more frequently used in the private sector.

On univariate analysis, patients with uncontrolled hypertension were significantly older, more frequently diabetic, obese and smokers. They were followed in the public sector, with more frequent history of strokes, and moderate renal failure 
antecedents. These patients had also higher pulse rate $(74.9 \pm 11.4 \mathrm{bpm}$ versus $72.5 \pm 10.5 \mathrm{bpm}, \mathrm{p}=<0.001)$. They practiced less frequently sport $(11.5 \%$ versus $18.1 \%, p<0.001)$ and are less compliant to the drug intake and the salt restriction.

Control of BP was better during the holly month (Ramadan), among 15239 hypertensive patients included during this month, with HTN history > 6 months, $53.3 \%$ individuals were in target.

Contrariwise, patients with controlled hypertension had more frequently a history of coronary diseases than others ( $19.9 \%$ versus $18.8 \%, p=0.033$ ), underwent more frequently electrocardiogram and echocardiography control and showed less frequently left ventricle hypertrophy (Table 2 ). 
Table 2

Comparison of patients with controlled blood pressure to those with uncontrolled blood Pressure, based on univariate analysis

\begin{tabular}{|c|c|c|c|c|}
\hline & $\begin{array}{l}\text { Patients with Know hypertension } \\
>6 \text { months }\end{array}$ & $\begin{array}{l}\text { Controlled } \\
\text { BP } \\
(<140 / 90)\end{array}$ & $\begin{array}{l}\text { Uncontrolled BP ( } \geq \\
140 / 90 \mathrm{mmHg} \text { ) }\end{array}$ & p \\
\hline $\mathbf{N}$ & 23601 & 12206 & 11395 & \\
\hline Age (years) & $65(18-118)$ & $65(18-118)$ & $65(18-104)$ & \multirow[t]{2}{*}{$0,022 *$} \\
\hline $\begin{array}{l}\text { Median ( min-max) } \\
\text { Mean } \pm \text { SD }\end{array}$ & $65.07 \pm 11.9$ & $\begin{array}{l}64,94 \pm \\
12,15\end{array}$ & $65.2 \pm 11.6$ & \\
\hline Male (\%) & $10543(44.7)$ & $5371(50.9)$ & $5172(49.1)$ & \multirow[t]{3}{*}{0.032} \\
\hline Female (\%) & 13058 (55.3) & $\begin{array}{l}6835 \\
(52.34)\end{array}$ & $6223(47.6)$ & \\
\hline Sex Ratio (F/M) & 1.23 & 1.23 & 1.27 & \\
\hline Public sector (\%) & $18613(78.9)$ & $9361(76.7)$ & 9252 (81.2) & $<10^{-3}$ \\
\hline Ramadan inclusion (\%) & $15239(64.6)$ & $8132(66.6)$ & 7107 (62.4) & $<10^{-3}$ \\
\hline Education level & 7182(30.4) & $3688(30.2)$ & $3494(30.7)$ & \multirow[t]{5}{*}{$<10^{-3}$} \\
\hline Unprecised (\%) & $5236(22.2)$ & 2588(21.2) & 2648(23.2) & \\
\hline Illiterate (\%) & $5111(21.7)$ & 2548(20.9) & $2563(22.5)$ & \\
\hline Primary school & $4041(17.1)$ & 2217(18.2) & $1824(16)$ & \\
\hline $\begin{array}{l}\text { Secondary school } \\
\text { University school }\end{array}$ & 2031(8.6) & $1165(9.5)$ & $866(7.6)$ & \\
\hline $\begin{array}{l}\text { Secondary/University } \\
\text { education }\end{array}$ & $6072(25.7)$ & $3382(27.7)$ & $2690(23.6)$ & $<10^{-3}$ \\
\hline
\end{tabular}

*mann-whitney nonparametric test

ABPM: Ambulatory blood pressure monitoring, ACE: Antagonist of conversion enzyme, ARB: Angiotensin Receptor Blockers, BMI: Body mass Index, CCB: Calcium Channels Blockers, COPD: Chronic obstructive pulmonary disease, DBP: Diastolic Blood Pressure, EKG: electrocardiogram, HTN: hypertension, LVH: Left Ventricle Hypertrophy, SD: Standard Deviation, SBP: systolic Blood Pressure, SMBP: Self measured Blood Pressure, TTE: Transthoracic echocardiography, Yo: year-old, 


\begin{tabular}{|c|c|c|c|c|}
\hline & $\begin{array}{l}\text { Patients with Know hypertension } \\
>6 \text { months }\end{array}$ & $\begin{array}{l}\text { Controlled } \\
\text { BP } \\
(<140 / 90)\end{array}$ & $\begin{array}{l}\text { Uncontrolled BP ( } \geq \\
140 / 90 \mathrm{mmHg})\end{array}$ & $p$ \\
\hline \multirow{8}{*}{$\begin{array}{l}\text { Health insurance } \\
\text { coverage } \\
\text { Private insurance } \\
\text { National insurance } \\
\text { Indigent } \\
\text { None } \\
\text { unprecised }\end{array}$} & $624(2.6)$ & $331(2.7)$ & 293(2.6) & \multirow{8}{*}{$<10^{-3}$} \\
\hline & 17021(72.1) & 9012(73.8) & $8009(70.3)$ & \\
\hline & \multirow[t]{4}{*}{$4746(20.1)$} & \multirow[t]{4}{*}{ 2275(18.6) } & \multirow[t]{4}{*}{ 2471(21.7) } & \\
\hline & & & & \\
\hline & & & & \\
\hline & & & & \\
\hline & $620(2.6)$ & $296(2.4)$ & $324(2.8)$ & \\
\hline & $590(2.5)$ & $292(2.4)$ & $298(2.6)$ & \\
\hline History of HTN & $1240(5.3)$ & $177(3.7)$ & $690(5.7)$ & $<10^{-3}$ \\
\hline$<1$ y $(\%)$ & $5922(25.1)$ & $1138(24.0)$ & 3280 (26.9) & \\
\hline 1 to $5 \mathrm{y}(\%)$ & 6293 (26.7) & $1434(30.3)$ & 3225 (26.4) & \\
\hline 5 to 10 y (\%) & 4620 (19.6) & 1486 (31.4) & 2261 (18.5) & \\
\hline 10 to 15 y (\%) & 3187 (13.5) & $503(10.6)$ & $148(12.1)$ & \\
\hline \multicolumn{5}{|l|}{ > 15 y (\%) } \\
\hline Smoking (\%) & $3226(13.7)$ & 1525(12.5) & 1701(14.9) & $<10^{-3}$ \\
\hline Diabetes (\%) & $9730(41.2)$ & $4738(38.8)$ & 4992(43.8) & $<10^{-3}$ \\
\hline Obesity (\%) & 6475(28.9) & 3178 (27.4) & 3297 (30.5) & $<10^{-3}$ \\
\hline BMI & $27.5(13-72)$ & \multirow{2}{*}{$\begin{array}{l}27.4(13.7- \\
67)\end{array}$} & $27.6(14.6-72)$ & \multirow{3}{*}{$\begin{array}{l}<10^{-} \\
3^{*}\end{array}$} \\
\hline Median ( min-max) & \multirow[t]{2}{*}{$28,1 \pm 4,5$} & & \multirow[t]{2}{*}{$28,4 \pm 4,6$} & \\
\hline Mean \pm SD & & & & \\
\hline $\begin{array}{l}\text { Moderate Renal Failure } \\
(\%)\end{array}$ & $1479(6.3)$ & $692(5.7)$ & $787(6.9)$ & $<10^{-3}$ \\
\hline Hypothyroidism (\%) & $1289(5.5)$ & $679(5.6)$ & $610(5.4)$ & 0.4 \\
\hline $\begin{array}{l}\text { Confirmed Apnea } \\
\text { syndrome (\%) }\end{array}$ & $443(1.9)$ & 201(1.6) & $242(2.1)$ & 0.004 \\
\hline \multicolumn{5}{|c|}{ *mann-whitney nonparametric test } \\
\hline \multicolumn{5}{|c|}{$\begin{array}{l}\text { ABPM: Ambulatory blood pressure monitoring, ACE: Antagonist of conversion enzyme, ARB: Angiotensin Receptor } \\
\text { Blockers, BMI: Body mass Index, CCB: Calcium Channels Blockers, COPD: Chronic obstructive pulmonary disease, DBP: } \\
\text { Diastolic Blood Pressure, EKG: electrocardiogram, HTN: hypertension, LVH: Left Ventricle Hypertrophy, SD: Standard } \\
\text { Deviation, SBP: systolic Blood Pressure, SMBP: Self measured Blood Pressure, TTE: Transthoracic echocardiography, } \\
\text { Yo: year-old, }\end{array}$} \\
\hline
\end{tabular}




\begin{tabular}{|c|c|c|c|c|}
\hline & $\begin{array}{l}\text { Patients with Know hypertension } \\
>6 \text { months }\end{array}$ & $\begin{array}{l}\text { Controlled } \\
\text { BP } \\
(<140 / 90)\end{array}$ & $\begin{array}{l}\text { Uncontrolled BP ( } \geq \\
140 / 90 \mathrm{mmHg})\end{array}$ & $\mathrm{p}$ \\
\hline COPD (\%) & $502(2.1)$ & $248(2)$ & $254(2.2)$ & 0.3 \\
\hline Stroke histoty (\%) & $1608(6.8)$ & $765(6.3)$ & $843(7.4)$ & $<10^{-3}$ \\
\hline Coronary disease (\%) & $4579(19.4)$ & 2433(19.9) & $2146(18.8)$ & 0.033 \\
\hline Median Heart rate & $73(40-150)$ & $71(40-150)$ & $75(40-150)$ & \multirow{2}{*}{$\begin{array}{l}<10^{-} \\
3^{*}\end{array}$} \\
\hline $\begin{array}{l}\text { Mean Heart rate } \pm \text { SD } \\
\text { (bpm) }\end{array}$ & $73.6 \pm 11$ & $72.4 \pm 10,5$ & $74.8 \pm 11,3$ & \\
\hline Heart rate > $80 \mathrm{bpm}(\%)$ & $4328(18.3)$ & 1773(14.6) & $2555(22.6)$ & $<10^{-3}$ \\
\hline LVH on EKG or TTE (\%) & $2728(11.6)$ & $1213(9.9)$ & $1515(13.3)$ & $<10^{-3}$ \\
\hline Atrial fibrillation (\%) & 1834(7.8) & $970(7.9)$ & $864(7.6)$ & 0.3 \\
\hline $\begin{array}{l}\text { Recent lab tests }<6 \\
\text { months }\end{array}$ & $13799(58.5)$ & $7331(60.1)$ & $6468(56.8)$ & $<10^{-3}$ \\
\hline $\begin{array}{l}\text { Fasting Glucose (mg/dl) } \\
\text { Median ( min-max) } \\
\text { Mean } \pm \text { SD) }\end{array}$ & $\begin{array}{l}1.1(0.5-3.9) \\
1.3 \pm 0.5\end{array}$ & $\begin{array}{l}1.1(0.5- \\
3.9) \\
1.6 \pm 4.4\end{array}$ & $\begin{array}{l}1.2(0.5-3.9) \\
1.9 \pm 6.1\end{array}$ & $\begin{array}{l}<10^{-} \\
3^{\star}\end{array}$ \\
\hline $\begin{array}{l}\text { Creatinine }(\mu \mathrm{mol} / \mathrm{l}) \\
\text { Median ( min-max) } \\
\text { Mean } \pm \mathrm{SD} \text { ) }\end{array}$ & $\begin{array}{l}82(30-700) \\
93.07 \pm 51,3\end{array}$ & $\begin{array}{l}80(30-700) \\
90.7 \pm 47,3\end{array}$ & $\begin{array}{l}83(32-681) \\
95.5 \pm 55,2\end{array}$ & $\begin{array}{l}<10^{-} \\
3^{\star}\end{array}$ \\
\hline $\begin{array}{l}\text { Creatinin clearance } \\
(\mathrm{ml} / \mathrm{min}) \\
\text { Median ( min-max) } \\
\text { Mean } \pm \mathrm{SD})\end{array}$ & $\begin{array}{l}87.9(7-287) \\
89.9 \pm 33.5\end{array}$ & $\begin{array}{l}89(7.34- \\
287) \\
91.2 \pm 32\end{array}$ & $\begin{array}{l}86.5(7.8-264) \\
88 \pm 34\end{array}$ & $\begin{array}{l}<10^{-} \\
3^{*}\end{array}$ \\
\hline $\begin{array}{l}\text { Total Cholesterol (mg/dl) } \\
\text { Median ( min-max) } \\
\text { Mean } \pm \text { SD) }\end{array}$ & $\begin{array}{l}1.8(1-5) \\
1.9 \pm 0.6\end{array}$ & $\begin{array}{l}1.8(1-5) \\
1.8 \pm 0.6\end{array}$ & $\begin{array}{l}1.8(1-5) \\
1.93 \pm 0.6\end{array}$ & $0.01 *$ \\
\hline $\begin{array}{l}\text { K+ (mmol/l) } \\
\text { Median ( min-max) } \\
\text { Mean } \pm \text { SD })\end{array}$ & $\begin{array}{l}4.1(2.4-7) \\
4.1 \pm 0.46\end{array}$ & $\begin{array}{l}4.1(2-7) \\
4.1 \pm 0.45\end{array}$ & $\begin{array}{l}4.1(2.5-7) \\
4.1 \pm 0.5\end{array}$ & $0.3^{*}$ \\
\hline Proteinuria (+) & $1306(5.5)$ & 616(10.7) & $690(13.3)$ & $<10^{-3}$ \\
\hline
\end{tabular}

*mann-whitney nonparametric test

ABPM: Ambulatory blood pressure monitoring, ACE: Antagonist of conversion enzyme, ARB: Angiotensin Receptor Blockers, BMl: Body mass Index, CCB: Calcium Channels Blockers, COPD: Chronic obstructive pulmonary disease, DBP: Diastolic Blood Pressure, EKG: electrocardiogram, HTN: hypertension, LVH: Left Ventricle Hypertrophy, SD: Standard Deviation, SBP: systolic Blood Pressure, SMBP: Self measured Blood Pressure, TTE: Transthoracic echocardiography, Yo: year-old, 


\begin{tabular}{|c|c|c|c|c|}
\hline & $\begin{array}{l}\text { Patients with Know hypertension } \\
>6 \text { months }\end{array}$ & $\begin{array}{l}\text { Controlled } \\
\text { BP } \\
(<140 / 90)\end{array}$ & $\begin{array}{l}\text { Uncontrolled BP }(\geq \\
140 / 90 \mathrm{mmHg})\end{array}$ & $\mathrm{p}$ \\
\hline \multicolumn{5}{|l|}{ Drug treatment } \\
\hline No drug (\%) & $3202(13.6)$ & $1583(13)$ & $1619(14.2)$ & \multirow[t]{4}{*}{$<10^{-3}$} \\
\hline Monotherapy (\%) & $10959(46.4)$ & $6294(51.6)$ & $4665(40.9)$ & \\
\hline Bitherapy (\%) & $6318(26.8)$ & $3131(25.7)$ & $3187(28.0)$ & \\
\hline Tritherapy or more (\%) & $3122(13.2)$ & 1198(9.8) & 1924(16.9) & \\
\hline \multicolumn{5}{|l|}{ Hypertensive drug } \\
\hline ACE (\%) & $10734(45.5)$ & $5602(45.9)$ & $5132(45)$ & 0.18 \\
\hline ARB (\%) & $5265(22.3)$ & $3033(24.8)$ & 2232(19.6) & $<10^{-3}$ \\
\hline CCB (\%) & 7324(31) & $3739(30.6)$ & $3585(31.5)$ & 0.16 \\
\hline Diuretics (\%) & $5018(21.3)$ & 2643(21.7) & 2375(20.8) & 0.12 \\
\hline Betablockers (\%) & $5239(22.2)$ & $2726(22.3)$ & 2513(22.1) & 0.6 \\
\hline $\begin{array}{l}\text { One single pill therapy } \\
(\%)\end{array}$ & $1506(6.3)$ & $766(3.2)$ & $740(3.4)$ & 0.829 \\
\hline Salt restriction (\%) & 13294(56.3) & $8189(67.1)$ & $5105(44.8)$ & $<10^{-3}$ \\
\hline ABPM (\%) & $493(2.1)$ & 231(1.9) & $262(2.3)$ & 0.02 \\
\hline SMBP (\%) & $1464(6.2)$ & $758(6.2)$ & $706(6.2)$ & 0.9 \\
\hline Drug compliance (\%) & 18824(79.8) & 10566(86.6) & $8258(72.5)$ & $<10^{-3}$ \\
\hline Physical activity (\%) & $3524(14.9)$ & 2210(18.1) & 1314(11.5) & $<10^{-3}$ \\
\hline \multicolumn{5}{|c|}{ *mann-whitney nonparametric test } \\
\hline \multicolumn{5}{|c|}{$\begin{array}{l}\text { ABPM: Ambulatory blood pressure monitoring, ACE: Antagonist of conversion enzyme, ARB: Angiotensin Receptor } \\
\text { Blockers, BMl: Body mass Index, CCB: Calcium Channels Blockers, COPD: Chronic obstructive pulmonary disease, DBP: } \\
\text { Diastolic Blood Pressure, EKG: electrocardiogram, HTN: hypertension, LVH: Left Ventricle Hypertrophy, SD: Standard } \\
\text { Deviation, SBP: systolic Blood Pressure, SMBP: Self measured Blood Pressure, TTE: Transthoracic echocardiography, } \\
\text { Yo: year-old, }\end{array}$} \\
\hline
\end{tabular}

Based on multivariate analysis, predictors of uncontrolled hypertension were of male gender, old age $>65$ yo, diabetic, obese, smokers, in public sector management, HR more than $80 \mathrm{bpm}$. Contrariwise, predictors of controlled hypertension were of high educational level (secondary/university), with a history of coronary disease, salt restriction, drug compliance and regular physic activity (Table 3 and Fig. 1). 
Table 3

Multivariate analysis: Independent predictors of Uncontrolled Blood Pressure

\begin{tabular}{|lccc|}
\hline & OR & $95 \%$ Cl & P value \\
\hline Male sex & 1.09 & $1.02-1.16$ & 0.006 \\
\hline Age $>65$ y o & 1.07 & $1.01-1.13$ & 0.017 \\
\hline University or secondary education & 0.909 & $0.84-0.97$ & 0.006 \\
\hline Diabetes & 1.18 & $1.11-1.25$ & $<10^{-3}$ \\
\hline Smoking & 1.15 & $1.05-1.25$ & 0.001 \\
\hline Obesity & 1.14 & $1.075-1.219$ & $<10^{-3}$ \\
\hline Coronary disease & 0.86 & $0.8-0.93$ & $<10^{-3}$ \\
\hline Public sector & 1.25 & $1.16-1.34$ & $<10^{-3}$ \\
\hline HR $>$ 80bpm & 1.59 & $1.48-1.71$ & $<10^{-3}$ \\
\hline Salt restriction & 0.48 & $0.45-0.51$ & $<10^{-3}$ \\
\hline Drug compliance & 0.57 & $0.52-0.61$ & $<10^{-3}$ \\
\hline Physical Activity & 0.77 & $0.71-0.84$ & $<10^{-3}$ \\
\hline Bpm: beat per minute, Cl: Confidence Interval, HR: Heart Rate, OR: odds Ration, Yo: year-old & \\
\hline
\end{tabular}

\section{Discussion}

Hypertension is the most prevalent cardiovascular factors worldwide and is the main cause of death even in developed country [17]. Recently a large meta-analysis of 2939 sudden cardiac deaths (SCD) among 418,235 participants from 18 studies, showed that hypertension is associated with a twofold increase in risk of SCD and a $28 \%$ increase of SCD per 20 $\mathrm{mmHg}$ increment in SBP [18]. Moreover, in a pooled dataset from 44 low-income and middle-income countries including 1100507 participants, the authors showed that only $10.3 \%$ of hypertensive patients achieved BP control [9]. All these indicators demonstrate that hypertension is a public health problem in developed as well as developing countries. Tunisia, is a mild incomes country, and during the last decade, the Tunisian lifestyle, eating habits and the population ageing have widely changed; there has been an increase in cardiovascular risk factor [19]. Recently a national cross sectional Tunisian study "ATERA", including 11955 individuals showed that the prevalence of high blood pressure has increased to 50\%, that of diabetes to $18 \%$ and that of obesity to $31 \%$ [20]. Face to these dramatic epidemiologic indicators, the Tunisian Society of Cardiology and Cardiovascular surgery, aimed to evaluate the cardiovascular profile of hypertensive patients and to assess the BP control, through a national flash study. In our knowledge, Nature HTN is the largest national survey of Hypertension in Africa. The most important findings of this registry is that the profile risk of the Tunisian has changed remarkably. In 2012, ben Romdhane et al published the results of TAHINA project, which was a Tunisian national survey including 8007 patients, aged between 35 and 70 years and examined across home visits. When comparing the results of TAHINA and Nature HTN among hypertensive patients, we found that the prevalence of illiterate people has decreased from 43-21.3\%. Surprisingly, we found that the prevalence of diabetes among hypertensive people has deacreased from $62-39.4 \%$, that of tobacco from $22-14 \%$ and that of obesity from $46-25 \%$ [11]. All these findings demonstrate that nowadays, the diagnosis of hypertension was made early before the development of diabetes and other comorbidities. That's why the rate of diabetic among hypertensive patients has decreased. This finding goes along with the improvement of the educational 
level between the two studies, certainly the Tunisian citizen 's awareness of blood pressure risks, and management methods has evidently increased.

The second important finding of our registry is the improvement of BP control; in 2005, Ben Romdhane et al had conducted a Tunisian cross-sectional survey on 1837 adults, aged between $40-69$ years old, only $13.2 \%$ of hypertensive individuals were controlled [7]. Then, hypertension control increased to $24.1 \%$ in the TAHINA project (2012) and recently we demonstrated in NATURE HTN that BP was controlled in $51.9 \%$ of our population when we consider $140 / 90$ as a target. This rate is close to the rate achieved in many developed countries. Control of hypertension remains elusive nationally, despite widespread availability of effective therapies.

In fact, control hypertension remains a health problem in not only low and middle incomes countries but also even in high incomes countries. Ikeda et al, in a comparative analysis of national surveys in 20 countries, showed that hypertension was treated in 13.8-80.5\% of hypertensive patients in the different countries but was controlled only in $4.4 \%$ to $59.1 \%$ [10]. Recently, Pan et al reported a control of $60 \%$ of hypertensive patients in Taiwan, but the prevalence of diabetes, obesity and smoking in this cohort were lower compared to our population [21].

In California, the implementation of a large-scale hypertension program has been associated with a significant increase in hypertension control compared to the others cities of US. The control rate increased from $55 \%$ in 2001 to $64 \%$ in 2009 . Key elements of this program included a comprehensive hypertension registry, development and sharing of performance metrics, evidence-based guidelines, medical assistant visits for blood pressure measurement, and single-pill combination pharmacotherapy [22].

Recently the FLASH 2019 study, a national French study has showed a rate of 54\% of BP control [23]. This rate was stable in between the different Flash studies (2009-2019), a therapeutic inertia was advanced to explain the lack of BP control improvement. The monotherapy kept downgrading in the different guidelines but Girerd et al reported that the rate of monotherapy has increased according to the different FLASH studies, changing from $44 \%$ in 2009 to $55 \%$ in 2019 , and he related the cause to the difficulties of drug reimbursement during the last years.

In our population, the BP control has improved, the reimbursement of Stage II and III hypertension costs as well as the availability of generic molecules, the improvement of the education level of the Tunisian population has certainly contributed to this achievement. However, management of patients in public sector was found as an independent predictor of uncontrolled hypertension. Certainly, this could be explained in part by the discrepancy of drug availability between the two sectors, the quality of health insurance and the lack of one single pill in public sector. However, we it is worth considering that we found in our cohort that patients treated in public sector seem to be at higher cardiovascular risk with higher prevalence obesity, diabetes, smoking with a less frequently physical activity. All these factors were identified as predictors of uncontrolled hypertension in our population and were behind the bad control of BP in public sector. Moreover, patients treated in the private sector, underwent more frequently out office measurement, they had lower heart rate, better follow up with more frequent lab test. We noted also that ARB Class was more frequently prescribed in private sector and this class is associated with better tolerance and persistence. In public sector, the majority of patients take their drugs from the hospital. ARB class was not available in public sector. All these findings should be considered by the health ministry to improve the conditions of management of hypertensive patients in public sector where patients with the highest cardiovascular profile were treated.

The reimbursement of stage I hypertension costs by the national security fund is another point to discuss and which is missing both, in private and public sector. There is an urgent need for a comprehensive integrated population-based intervention program to improve the growing problem of hypertension in Tunisia.

Heart rate was another strong predictor of uncontrolled BP in our population and this is could be related to the big prevalence of overweight and obesity as well as the low physical activity practice. One patient out of five has a heart rate > 
$80 \mathrm{bpm}$ in our model. Recently, the ESC/ESH guidelines classified this clinical finding among the factors influencing cardiovascular risk $[14,24]$. The Nice guidelines recommended to downgrade beta-blockers use and to limit their use to the specific settings [25], but we thought that sympathic activation is well involved in the physiopathology of hypertension in Tunisian people, as it was demonstrated by the high Heart rate in our population [26]. Therapeutic education should be highly considered and practicing sports to reduce BP level highly recommended. In developed countries, $60 \%$ of the population practice sport regularly [27], in our study only $14 \%$ performed a physical activity. Recently, Sata rosa et al showed that active life style improves heart rate variability as well as reduces oxidative stress in hypertensive people and it improves BP control [28]. On the other hand, Beta blockers should not be dismissed, and patients with high HR, definitely need this therapeutic class.

Patients with a history of coronary disease were more in target in our model and ischemic cardiomyoapthy was even identified as a predictor of controlled blood pressure. Many previous studies have confirmed these findings $[6,7,10,29]$, in fact patients with coronary disease are more compliant to their drugs and generally receive at least two class (beta blockers and ACE or ARB), moreover they consult their doctors more frequently.

\section{Limits Of The Study}

The main limit of our registry that it included only confirmed patients and didn't aim to assess the prevalence of hypertension, the rate of undiagnosed and non-treated hypertensive patients. If all these groups were considered, the control rate would be lower.

On the other hand, the definition of hypertension control was based on office measurements, we did not complete with a systematic out office measurements to check the white blouse high blood pressure effect, therefore the rate of uncontrolled patients could be over-estimated in this registry.

Finally, this cross sectional study did not evaluate the clinical follow up and the impact of uncontrolled blood pressure on cardiovascular events.

\section{Conclusions}

Nature HTN is the largest national survey of hypertension in Tunisia, it would contribute to analyze the burden of hypertension in a developing country, and highlight the important gaps in the treatment of hypertensive individuals. Certainly, it may help to guide the implementation of future interventions and to write national guidelines. The most important finding of this registry is that the control of hypertension has remarkably improved over the last years, although a high cardiovascular risk of our population. Therapeutic education along with substantial support and interest to the public sector are important preventive measure that can contribute to the public health in Tunisia.

\section{Declarations}

\section{Ethics approval and consent to participate}

An ethical approval letter has been obtained from the ethic committee of the Hospital of the Internal Security Forces. A written consent was obtained from all subjects. In case of illiterate participants written consent was obtained from legal guardians.

\section{Consent for publication}

Not applicable 


\section{Availability of data and materials}

Data cannot be shared publicly because of privacy concern. Indeed, data might reveal the identity and the location of participants included into the study. Data are available from the Tunisian Society of Cardiology and Cardiovascular Surgery Ethics Committee (contact via Résidence les pergolas, Rue du Lac Huron Appartement 201, Berges du Lac Tunisie, Email: secretaire.stcccv@gmail.com; Tel: (+216) 71965 432) for researchers who meet the criteria for access to confidential data. there were no administrative permissions required to access the raw data from.

\section{Competing interests}

Authors declare that they have no conflict of interest.

\section{Funding}

Not applicable

\section{Authors' contributions}

Leila Abid was a principal investigator.Rania Hammami was a major contributor in writing the manuscript. Yosra Mejdoub performed statistical analyzes. The other authors were investigators, they included their patients. All authors read and approved the final manuscript.

Imen gtif is a co-author and an investigator.

\section{Acknowledgment}

I would like to offer my special thanks to Professor Rania Khelil for her great help and constructive suggestions for revising the English language of this work.

\section{References}

1. NCD Risk Factor Collaboration (NCD-RisC). Worldwide trends in blood pressure from 1975 to 2015: a pooled analysis of 1479 population-based measurement studies with 19.1 million participants. Lancet 2017; 389:37-55.

2. Kearney PM, Whelton M, Reynolds K, Muntner P, Whelton PK, He J. Global burden of hypertension: analysis of worldwide data. Lancet 2005; 365:217-223.

3. Chow CK, Teo KK, Rangarajan S, Islam S, Gupta R, Avezum A, et al. Prevalence, awareness, treatment, and control of hypertension in rural and urban communities in high-, middle-, and low-income countries. JAMA 2013; 310:959-968.

4. Cifkova R, Fodor G, Wohlfahrt P. Changes in Hypertension Prevalence, Awareness, Treatment, and Control in High-, Middle-, and Low-Income Countries: An Update. Curr Hypertens Rep 2016; 18:62.

5. Sarki AM, Nduka CU, Stranges S, Kandala N-B, Uthman OA. Prevalence of Hypertension in Low- and Middle-Income Countries: A Systematic Review and Meta-Analysis. Medicine (Baltimore) 2015; 94:e1959.

6. Whelton PK, He J, Muntner P. Prevalence, awareness, treatment and control of hypertension in North America, North Africa and Asia. J Hum Hypertens 2004; 18:545-551.

7. Ben Romdhane H, Skhiri H, Bougatef S, Ennigrou S, Gharbi D, Chahed MK, et al. [Hypertension prevalence, awareness, treatment and control: results from a community based survey]. Tunis Med 2005; 83 Suppl 5:41-46. 
8. Prenissl J, Manne-Goehler J, Jaacks LM, Prabhakaran D, Awasthi A, Bischops AC, et al. Hypertension screening, awareness, treatment, and control in India: A nationally representative cross-sectional study among individuals aged 15 to 49 years. PLoS Med 2019; 16:e1002801.

9. Geldsetzer P, Manne-Goehler J, Marcus M-E, Ebert C, Zhumadilov Z, Wesseh CS, et al. The state of hypertension care in 44 low-income and middle-income countries: a cross-sectional study of nationally representative individual-level data from 1·1 million adults. Lancet 2019; 394:652-662.

10. Ikeda N, Sapienza D, Guerrero R, Aekplakorn W, Naghavi M, Mokdad AH, et al. Control of hypertension with medication: a comparative analysis of national surveys in 20 countries. Bull World Health Organ 2014; 92:10-19C.

11. Ben Romdhane H, Ben Ali S, Skhiri H, Traissac P, Bougatef S, Maire B, et al. Hypertension among Tunisian adults: results of the TAHINA project. Hypertens Res 2012; 35:341-347.

12. Piepoli MF, Hoes AW, Agewall S, Albus C, Brotons C, Catapano AL, et al. 2016 European Guidelines on cardiovascular disease prevention in clinical practiceThe Sixth Joint Task Force of the European Society of Cardiology and Other Societies on Cardiovascular Disease Prevention in Clinical Practice (constituted by representatives of 10 societies and by invited experts)Developed with the special contribution of the European Association for Cardiovascular Prevention \& Rehabilitation (EACPR). Eur Heart J 2016; 37:2315-2381.

13. Saeedi P, Petersohn I, Salpea P, Malanda B, Karuranga S, Unwin N, et al. Global and regional diabetes prevalence estimates for 2019 and projections for 2030 and 2045: Results from the International Diabetes Federation Diabetes Atlas, 9th edition. Diabetes Res Clin Pract 2019; 157:107843.

14. Williams B, Mancia G, Spiering W, Agabiti Rosei E, Azizi M, Burnier M, et al. 2018 ESC/ESH Guidelines for the management of arterial hypertensionThe Task Force for the management of arterial hypertension of the European Society of Cardiology (ESC) and the European Society of Hypertension (ESH). Eur Heart J 2018; 39:3021-3104.

15. Levey AS, Stevens LA, Schmid CH, Zhang YL, Castro AF, Feldman HI, et al. A new equation to estimate glomerular filtration rate. Ann Intern Med 2009; 150:604-612.

16. NCD Risk Factor Collaboration (NCD-RisC). Worldwide trends in body-mass index, underweight, overweight, and obesity from 1975 to 2016: a pooled analysis of 2416 population-based measurement studies in 128.9 million children, adolescents, and adults. Lancet 2017; 390:2627-2642.

17. Zeng Z, Chen J, Xiao C, Chen W. A Global View on Prevalence of Hypertension and Human Develop Index. Ann Glob Health 2020; 86:67.

18. Pan H, Hibino M, Kobeissi E, Aune D. Blood pressure, hypertension and the risk of sudden cardiac death: a systematic review and meta-analysis of cohort studies. Eur J Epidemiol Published Online First: 24 December 2019.

doi:10.1007/s10654-019-00593-4

19. Ben Ayed H, Ben Jemaa M, Trigui M, Ben Hmida M, Kassis M, Jedidi J, et al. Cardiovascular diseases in Southern Tunisia: current trends and future projections. Tunis Med 2019; 97:659-666.

20. Jemaa R, Razgallah R, Ben Ghorbel I, Rais L, Kallel A. Prevalence of cardiovascular risk factors in the Tunisian population: The ATERA-survey. Archives of Cardiovascular Diseases Supplements 2020; 12:159.

21. Pan H-Y, Lin H-J, Chen W-J, Wang T-D. Prevalence, Treatment, Control and Monitoring of Hypertension: A Nationwide Community-Based Survey in Taiwan, 2017. Acta Cardiol Sin 2020; 36:375-381.

22. Jaffe MG, Lee GA, Young JD, Sidney S, Go AS. Improved blood pressure control associated with a large-scale hypertension program. JAMA 2013; 310:699-705.

23. Girerd Xavier. Prise en charge de l'HTA en France: rien ne va plus. Medscape. http://francais.medscape.com/voirarticle/3605539 (accessed 8 Aug2020).

24. Julius S, Palatini P, Kjeldsen SE, Zanchetti A, Weber MA, Mclnnes GT, et al. Usefulness of heart rate to predict cardiac events in treated patients with high-risk systemic hypertension. Am J Cardiol 2012; 109:685-692. 
25. Krause T, Lovibond K, Caulfield M, McCormack T, Williams B, Guideline Development Group. Management of hypertension: summary of NICE guidance. BMJ 2011; 343:d4891.

26. Esler M, Lambert G, Esler D, Ika Sari C, Guo L, Jennings G. Evaluation of elevated heart rate as a sympathetic nervous system biomarker in essential hypertension. Journal of Hypertension 2020; 38:1488-1495.

27. Salman A, Sellami M, Al-Mohannadi AS, Chun S. The Associations between Mental Well-Being and Adherence to Physical Activity Guidelines in Patients with Cardiovascular Disease: Results from the Scottish Health Survey. Int $J$ Environ Res Public Health 2019; 16. doi:10.3390/ijerph16193596

28. Santa-Rosa FA, Shimojo GL, Dias DS, Viana A, Lanza FC, Irigoyen MC, et al. Impact of an active lifestyle on heart rate variability and oxidative stress markers in offspring of hypertensives. Sci Rep 2020; 10:12439.

29. Vedanthan R, Kamano JH, DeLong AK, Naanyu V, Binanay CA, Bloomfield GS, et al. Community Health Workers Improve Linkage to Hypertension Care in Western Kenya. J Am Coll Cardiol 2019; 74:1897-1906.

\section{Figures}

$\begin{array}{llr} & \text { OR }(95 \% \mathrm{Cl}) & \text { p valu } \\ \text { Male sex } & 1.09(1.02-1.16) & 0.00 \\ \text { Age }>65 \text { y o } & 1.07(1.01-1.13) & 0.01 \\ \text { University/secondary education } & 0.91(0.84-0.97) & 0.00 \\ \text { Diabetes } & 1.18(1.11-1.25) & <10 \\ \text { Smoking } & 1.15(1.05-1.25) & 0.00 \\ \text { Obesity } & 1.14(1.07-1.21) & <10 \\ \text { Coronary disease } & 0.86(0.8-0.93) & <10 \\ \text { Public sector } & 1.25(1.16-1.34) & <10 \\ \text { HR }>\text { 80bpm } & 1.59(1.48-1.71) & <10 \\ \text { Salt restriction } & 0.48(0.45-0.51) & <10 \\ \text { Drug compliance } & 0.57(0.52-0.61) & <10 \\ \text { Physical activity } & 0.77(0.71-0.84) & <10\end{array}$

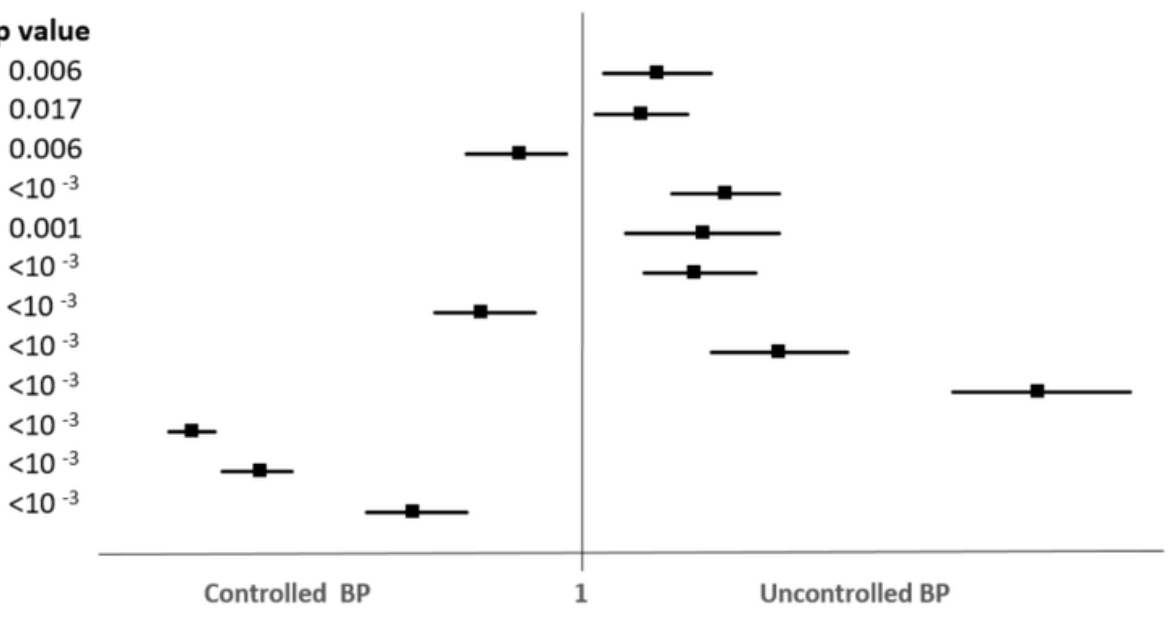

\section{Figure 1}

Forest Plot graph: Predictors of Blood pressure control according to the Multivariate regression analysis BP: Blood Pressure, bpm: beat per minute, Cl: confidence Interval, HR: Heart rate, OR: odd ratio, Yo: year old 